\title{
Phosphatidylinositol 3-kinase activation is required for insulin-stimulated sodium transport in A6 cells
}

\author{
RAE D. RECORD, ${ }^{1}$ LARRY L. FROELICH ${ }^{2}$ CHRIS J . VLAHOS, ${ }^{2}$ \\ AND BONNIE L. BLAZER-YOST ${ }^{1}$ \\ ${ }^{1}$ Roudebush Veterans Medical Center and Biology Department, \\ I ndiana University-Purdue University at Indianapol is, Indianapol is, 46202; \\ and 'Lilly Research Laboratories, Eli Lilly, Indianapolis, Indiana 46285
}

\begin{abstract}
Record, Rae D., Larry L. Froelich, Chris J . Vlahos, and Bonnie L. B lazer-Yost. Phosphatidylinositol 3-kinase activation is required for insulin-stimulated sodium transport in A6 cells. Am. J . Physiol . 274 (Endocrinol. Metab. 37): E611-E617, 1998.-Insulin stimulates amiloride-sensitive sodium transport in models of the distal nephron. Here we demonstrate that, in the A6 cell line, this action is mediated by the insulin receptor tyrosine kinase and that activation of phosphatidylinositol 3-kinase (PI 3-kinase) lies downstream of the receptor tyrosinekinase. F unctionally, a specific inhibitor of PI 3-kinase, LY-294002, blocks basal as well as insulinstimulated sodium transport in a dose-dependent manner $\left(\mathrm{IC}_{50} \approx 6 \mu \mathrm{M}\right)$. Biochemically, PI 3-kinase is present in A6 cells and is inhibited both in vivo and in vitro by LY-294002. Furthermore, a subsequent potential downstream signaling element, pp70 S6 kinase, is activated in response to insulin but does not appear to be part of the pathway involved in insulin-stimulated sodium transport. Together with previous reports, these results suggest that insulin may induce the exocytotic insertion of sodium channels into the apical membrane of A6 cells in a PI 3-kinase-mediated manner.
\end{abstract}

amiloride-sensitive sodium channel; insulin signaling; receptor tyrosinekinase; renal epithelia

INSULIN INCREASES SODIUM REABSORPTION in dogs and humans, and this effect appears to be manifested predominantly on the renal distal nephron $(21,10)$. Models of the distal nephron, toad urinary bladder (Bufo marinus) and the A6 cell line (derived from Xenopus laevis kidney), have been used to demonstrate a direct effect of insulin on amiloride-sensitive sodium transport $(12,14)$. Patch-clamp electrophysiology has indicated that insulin causes an increase in the open probability $\left(P_{O}\right)$ of the apical sodium channel (20). However, blocker-induced noise analysis demonstrated that insulin induces an increase in active sodium channel density in the apical membrane $(2,4,11)$. In addition, insulin increases the apical membrane area (11). These results suggest that insulin may induce the insertion of sodium channels into the apical membrane, a hypothesis supported by our study demonstrating that brefeldin $A$, an inhibitor of secretion, partially inhibits insulin-stimulated sodium transport (9).

Thefirst step in insulin signaling is the binding of the hormone to its receptor, followed by autophosphorylation of the receptor and subsequent activation of the receptor tyrosine kinase (IRTK). IRTK has several substrates, including the insulin receptor substrate (IRS) proteins (33). The IRS proteins mediate some of the pleiotropic effects of insulin through interactions with proteins containing $\mathrm{SH} 2$ domains, including phos- phatidylinositol 3-kinase (PI 3-kinase). This enzyme, a heterodimer, phosphorylates the D-3 position of the myo-inositol ring of phosphatidylinositols (Ptdlns; 17). PI 3-kinase is required for several insulin-mediated effects, including the translocation of the insulinresponsive glucose transporter (GLUT-4) to the plasma membrane of adipocytes (7) and skeletal muscle (34), and the activation of pp70 S6 kinase, which is necessary for protein synthesis (24).

We have previously demonstrated that insulin binds to the basolateral membrane of amphibian cells (5) and, along with others, that genistein, a tyrosine kinase inhibitor, decreases insulin-stimulated sodium transport $(25,27)$. Here we demonstrate that, in A6 cells, an IRTK inhibitor blocks insulin-stimulated sodium transport and that a specific PI 3-kinase inhibitor blocks insulin-stimulated sodium transport in a dose-dependent manner. We also show that, in the A6 cell line, insulin stimulates PI 3-kinase in vivo. In addition, our functional and biochemical studies indicate that pp70 S6 kinase is present in these cells and is activated by insulin but is not involved in insulin-stimulated sodium transport. These results suggest that PI 3-kinase is necessary for insulin-stimulated sodium transport, perhaps by mediating the insertion of sodium channels into the apical membrane in a manner analogous to the insulin-stimulated insertion of GLUT-4.

\section{EXPERIME NTAL PROCEDURES}

Materials. Hydroxy-2-naphthalenylmethylphosphonic acid tris acetoxymethyl ester [HNMPA-(AM $)_{3}$ ] and 2-(4-morpholinyl)-8-phenyl-4H-1-benzopyran-4-one (LY-294002) were purchased from BIOMOL Research Laboratories. Wortmannin, amiloride, Ptdlns, and PBS were purchased from Sigma Chemical. The wortmannin used has been shown to be active against mammalian $\mathrm{PI}$ 3-kinase. [ $\left.{ }^{32} \mathrm{P}\right] \mathrm{H}_{3} \mathrm{PO}_{4}$ was purchased from Du Pont NEN. [ $\gamma$-32P]ATP was purchased from Amersham Life Science. The anti-PI 3-kinase 85-kDa subunit, anti-pp70 S6 kinase, S6 kinase substrate, and an inhibitor cocktail for S6 kinase assay were purchased from Upstate Biotechnology. Porcine insulin was a generous gift from Eli Lilly. Rapamycin was purchased from ICN Pharmaceuticals. Transwell inserts were purchased from Costar. GammaBind Plus Sepharose beads were purchased from Pharmacia Biotech. Silica gel thin-layer chromatography plates, 60A, were purchased through Curtin Matheson Scientific. Media were purchased from GIBCO-BRL Life Technologies. 4-(2-Aminoethyl)-benzenesulfonyl fluoride hydrochloride (AEBSF) was obtained from Boehringer Mannheim.

Cell culture The A6 cell line was obtained from American Type Tissue Culture Collection and grown at $27^{\circ} \mathrm{C}$ in a humidified incubator gassed with $5 \% \mathrm{CO}_{2}$ in $\mathrm{O}_{2}$, as previously 
described (3). For electrophysiology, cells were subcultured onto 24-mm Transwell inserts; for biochemistry, cells were subcultured onto 24- or 100-mm Transwell inserts. Cells were used 14- 21 days after seeding.

Electrophysiology. Short-circuit current (SCC) techniques were used to determine net ion flux $(19,22)$. Cells grown on Transwell inserts were placed in a modified Ussing chamber and monitored as previously described (3). During the electrophysiological studies, cells were bathed in serum-free media maintained at $27^{\circ} \mathrm{C}$, with gentle circulation provided by a $5 \%$ $\mathrm{CO}_{2}-95 \% \mathrm{O}_{2}$ gas lift. Four chambers allowed simultaneous monitoring of cells grown in tandem. The monolayers were monitored until a stable baseline SCC was obtained (typically 0.5- $2 \mathrm{~h}$ ). The average starting currents (after basel ine stabilization) in these experiments varied from 2.7 to $18.9 \mu \mathrm{A} / \mathrm{cm}^{2}$. There was some variation between the starting currents in the different sets of experiments; however, within each experimental protocol, the average starting currents of the cells in all conditions were statistically the same value. The addition of amiloride at the end of each experiment verified that the majority of the SCC was due to net apical-to-serosal $\mathrm{Na}^{+}$flux, as previously reported for A6 cells. Transcellular resistance was determined every $2 \mathrm{~min}$ via a brief $2-\mathrm{mV}$ pulse across the cells. The average transcellular resistance varied from 1,372 to $3,075 \Omega \cdot \mathrm{cm}^{2}$. None of the inhibitors caused a significant decrease in the transepithelial resistance over the time course of the experimental protocols.

Porcine insulin was added to the serosal bathing medium. HNMPA-(AM) $)_{3}$, wortmannin, LY-294002, and rapamycin were dissolved in DMSO and added bilaterally. Amiloride, dissolved in methanol, was added to the apical bathing medium. Equal volumes of DMSO were added to the control tissues to detect any carrier effects; none were detected.

The change in SCC ( $\triangle S C C)$ in experimental (e) relative to control (c) samples was calculated using the following formula: $\Delta \mathrm{SCC}=[\mathrm{SCC}(\mathrm{t})-\mathrm{SCC}(0)]_{\mathrm{e}}-[\mathrm{SCC}(\mathrm{t})-\mathrm{SCC}(0)]_{\mathrm{c}}$ where SCC(t) is SCC at time t after insulin addition (with or without inhibitor preincubation), and SCC(0) is the SCC at thetime of insulin addition (with or without inhibitor pretreatment).

PI 3-kinase assay, in vitro. PI 3-kinase activity was determined by measuring the transfer of ${ }^{32} \mathrm{P}$ from [ $\gamma$-32P]ATP to PI to form [ $\left.{ }^{32} \mathrm{P}\right] \mathrm{PI}-3$, which was detected by thin-layer chromatography. A6 cells cultured on Transwell inserts were incubated in serum-free media for $16 \mathrm{~h}$. The cells were incubated with or without $100 \mathrm{nM}$ insulin in serum-free media for $5 \mathrm{~min}$ followed by one wash with ice-cold PBS. I ce-cold immunoprecipitation buffer (10 mM Tris, pH 7.4, 1\% Triton X-100, 150 $\mathrm{mM} \mathrm{NaCl}, 0.5 \%$ nonidet P-40, 1 mM EDTA, 1 mM EGTA, 0.2 $\mathrm{mM}$ sodium vanadate, $0.2 \mathrm{mM}$ AEBSF, $100 \mathrm{mM}$ sodium fluoride) was added to the filters, and the cells were scraped off with a rubber policeman. The cells were transferred to microtubes and incubated for $30 \mathrm{~min}$ at $4^{\circ} \mathrm{C}$ with occasional vortexing. The samples were centrifuged $\left(16,000 \mathrm{~g}_{\max }\right)$ for 15 min in a cold room. The supernatant (containing soluble proteins) was incubated with anti-PI 3-kinase (against the $85-\mathrm{kDa}$ subunit) and GammaBind beads for $4 \mathrm{~h}$ at $4^{\circ} \mathrm{C}$ with constant rotation. The beads were washed once in ice-cold PBS; twice in $0.5 \mathrm{M} \mathrm{LiCl}, 0.1 \mathrm{M}$ Tris, $\mathrm{pH}$ 7.5; and once in PI 3-kinase assay buffer ( $10 \mathrm{mM} \mathrm{MgCl}_{2}$ and $20 \mathrm{mM} \mathrm{HEPES}, \mathrm{pH}$ 7.4).

Theamount of PI 3-kinase activity in the immunoprecipitations was determined as previously described (23). The reaction was stopped with $\mathrm{HCl}$, and the lipids were extracted with methanol-chloroform (1:1 by volume). The lipids were applied to a silica gel thin-layer chromatography plate; the residue was developed with chloroform-methanol-water- ammonium hydroxide (45:35:8.5:1.5 by volume). The plate was dried and autoradiographed.

PI 3-kinase activity, in vivo. PI 3-kinase activity was determined by directly measuring the insulin-stimulated products of $\mathrm{PI} 3$-kinase $\left\{{ }^{32} \mathrm{P}\right] \mathrm{l}-3 \mathrm{P},\left[{ }^{32} \mathrm{P}\right] \mathrm{I}-(3,4) \mathrm{P}_{2}$, and $\left[{ }^{32} \mathrm{P}\right] \mathrm{I}-$ $(3,4,5) \mathrm{P}\}$ by use of anion exchange chromatography and an on-line radiochemical detector. A6 cells subcultured onto 100-mm Transwell inserts and grown to confluency were incubated in serum-free media for $16 \mathrm{~h}$. Subsequently, the cells were incubated in phosphate-free media containing 0.5 $\mathrm{mCi} /$ plate $\left[{ }^{32} \mathrm{P}\right] \mathrm{H}_{3} \mathrm{PO}_{4}$ for $2 \mathrm{~h}$. The cells were incubated with or without $25 \mathrm{nM}$ wortmannin or $50 \mu \mathrm{M}$ LY-294002 for $20 \mathrm{~min}$. The medium was removed, and the cells were washed twice with phosphate-free medium with or without inhibitor. The cells were incubated for $1 \mathrm{~min}$ in $100 \mathrm{nM}$ insulin, serosally, with or without inhibitor, followed by the addition of $1 \mathrm{~N}$ $\mathrm{HCl}$-methanol (1:1 by volume). The cells werescraped and the lipids extracted as reported (13). After thin-layer chromatography and autoradiography, the lipids were deacylated by treatment with methylamine (8) and separated by anionexchange HPLC.

pp70 S6 kinaseassay. A6 cells, serum starved for $16 \mathrm{~h}$, were treated for $30 \mathrm{~min}$ with or without $100 \mathrm{nM}$ rapamycin followed by $10 \mathrm{~min}$ in the presence or absence of $100 \mathrm{nM}$ insulin. Immunoprecipitations were performed as above, with the inclusion of $10 \mathrm{mM} \beta$-glycerophosphate in the immunoprecipitation buffer. A polyclonal antibody raised against a peptide corresponding to a post- $\mathrm{NH}_{2}$-terminal region of the human pp70 S6 kinase was used for enzyme isolation. The immunoprecipitates were washed three times in immunoprecipitation buffer followed by two washes in 56 kinase assay buffer [(in mM) 20 MOPS, pH 7.2, $25 \beta$ glycerophosphate, 5 EGTA, 1 orthovanadate, 1 dithiothreitol]. The washed immunoprecipitates were incubated in $10 \mu \mathrm{l}$ of S6 kinase assay buffer, $10 \mu \mathrm{l}$ inhibitor cocktail, $10 \mu \mathrm{l}$ S6 kinase assay buffer with or without substrate (11-amino acid peptide), and $10 \mu \mathrm{l}$ of [ $\gamma$-32P]ATP mixture $(0.2 \mathrm{mCi} / \mathrm{ml}, 112.5$ $\mu \mathrm{M}$ ATP, $16.9 \mathrm{mM} \mathrm{MgCl}$, final concentrations) for $20 \mathrm{~min}$ at $30^{\circ} \mathrm{C}$. An aliquot of the reaction mixture was placed on phosphocellulose paper followed by three washes in $0.7 \%$ phosphoric acid and one wash in acetone. The radioactivity was determined with a scintillation counter. Samples without immunoprecipitates (blanks) were run for background determinations. All samples were run in duplicate and averaged. The blanks were subtracted from the samples, and the endogenous substrate activity (samples without added substrate) was subtracted from the specific substrate activity.

\section{RESULTS}

We previously demonstrated that insulin binds to the basolateral membrane and that the insulin receptor is predominantly localized to the same membrane of amphibian cells (5). To demonstrate that insulinstimulated sodium transport requires the IRTK, we added HNMPA-(AM) $)_{3}(5 \mu \mathrm{g} / \mathrm{ml})$, a specific inhibitor of IRTK (1), $60 \mathrm{~min}$ before the addition of $20 \mathrm{nM}$ insulin (Fig. 1). HNMPA-(AM) $)_{3}$ inhibited insulin-stimulated sodium transport $\sim 50 \%$. This suggests that insulin stimulation of sodium transport is mediated through IRTK.

Earlier studies by us and others $(2,4,11)$ have demonstrated that insulin stimulates an increase in the number of active sodium channels into the apical membrane. Insulin induces the insertion of GLUT-4, another transporter, into the plasma membrane in a PI 

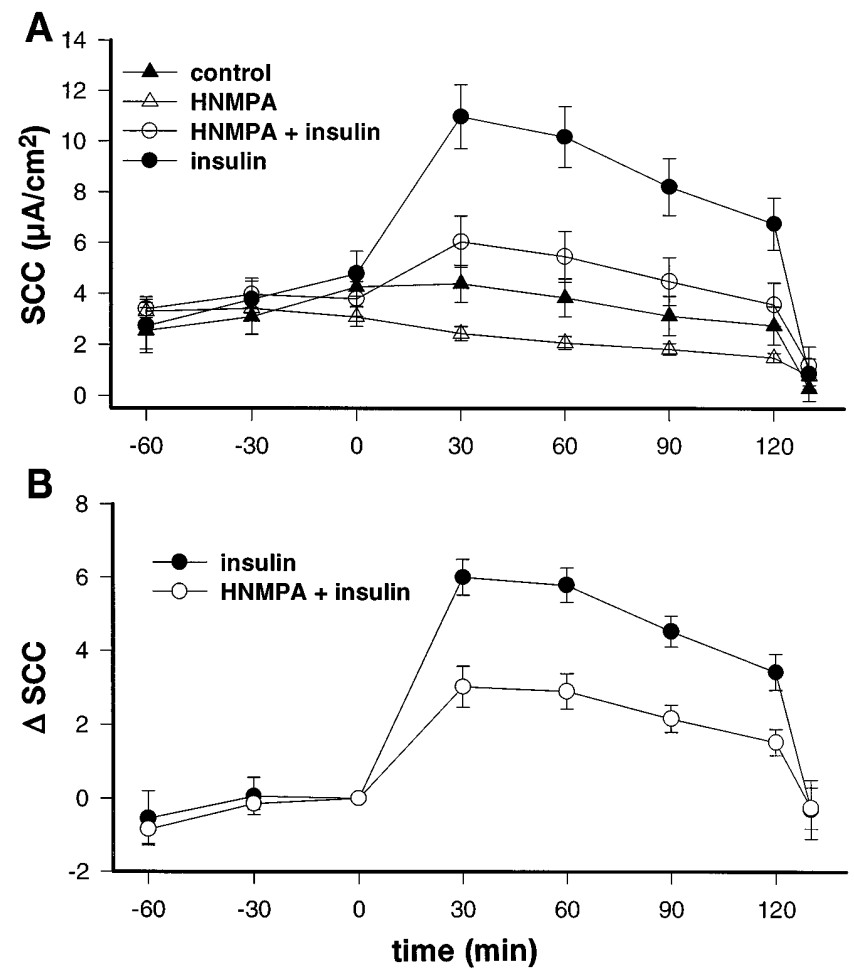

Fig. 1. Hydroxy-2-naphthalenylmethylphosphonic acid tris acetoxymethyl ester [HNMPA-(AM) $)_{3}$ inhibits insulin-stimulated sodium transport. A6 cells were preincubated with $5 \mu \mathrm{g} / \mathrm{ml}$ HNMPA-(AM) $)_{3}$ bilaterally for $60 \mathrm{~min}$. Insulin ( $20 \mathrm{nM}$ ) was added serosally at time 0 . After 120 min of insulin, $10 \mu \mathrm{M}$ amiloride was added apically. Results are means $\pm \mathrm{SE} ; \mathrm{n}=6$. $\mathrm{A}$ : actual data for all conditions. $\mathrm{B}$ : increase in short-circuit current (SCC) in response to insulin and relative to the appropriate control. $\triangle$ SCC is calculated as described in Experimental Procedures.

3-kinase-dependent manner $(7,34)$. To investigate whether PI 3-kinase was necessary for insulin-stimulated sodium transport, we initially used wortmannin, a fungal metabolite, which inhibits PI 3-kinase with an $\mathrm{IC}_{50}$ of 1.8-4.0 nM in 3T3 cells (23). However, $25 \mathrm{nM}$ wortmannin did not inhibit insulin-stimulated sodium transport (Fig. 2). At a concentration of $100 \mathrm{nM}$, wortmannin had an effect on basal transport and partially inhibited only the initial (30-min) response to insulin (Fig. 2).

A more specific inhibitor of PI 3-kinase, LY-294002 (32), blocked both basal and insulin-stimulated sodium transport in a dose-dependent manner (Fig. 3). The lowest concentration, $2 \mu \mathrm{M}$, had no effect, whereas 50 $\mu \mathrm{M}$ inhibited $\sim 90 \%$ of insulin-stimulated sodium transport. Graphing this limited dose-response curve yiel ded an $I_{50}$ of $\sim 6 \mu \mathrm{M}$ (Fig. 4), which is comparable to the reported I $C_{50}$ of $1.4 \mu \mathrm{M}$ (32).

The effects of insulin on transcellular $\mathrm{Na}^{+}$transport are manifested quite rapidly. Figure 5 illustrates the very early time course of the insulin response. Because activation of the signal transduction mechanism would be expected to precede the final effect on ion flux, the biochemical assays were designed to examine effects within the early phase of the insulin response.

To determine whether the LY-294002 effect was due to PI 3-kinase inhibition, we immunoprecipitated PI 3-kinase from A6 cells and assayed the activity associated with the immunoprecipitates (Fig. 6). In agreement with the electrophysiology studies, immunoprecipitated PI 3-kinase activity was inhibited by $50 \mu \mathrm{M}$ LY-294002, whereas wortmannin (25 nM) had little or no effect. As has been reported (31), treating the cells with insulin did not increase the amount of PI 3-kinase activity in immunoprecipitates.

We also examined the ability of insulin to stimulate the formation of D-3 phosphorylated phosphoinositides in vivo. As seen in Fig. 7, Ptdl ns(3)P, Ptdl ns(3,4)P, and Ptdlns $(3,4,5) P$ increase with insulin treatment $(100$ $\mathrm{nM}$; 1 min). Wortmannin (25 nM) inhibited the insulinstimulated formation of Ptdl ns(3)P and Ptdlns(3,4)P but not Ptdl ns(3,4,5)P. LY-294002 $(50 \mu \mathrm{M})$ inhibited production of all three products, preventing the formation of any detectable Ptdl ns $(3,4,5) P$. Together, these results suggest that $\mathrm{PI} 3$-kinase is present in A6 cells and can be stimulated by insulin. Furthermore, the A6 cell PI 3-kinase is inhibited by LY-294002, partially inhibited by wortmannin, and is critical for insulinstimulated sodium transport.

pp70 S6 kinase is one of the insulin-stimulated elements downstream of PI 3-kinase necessary for several metabolic actions (7). To determine whether
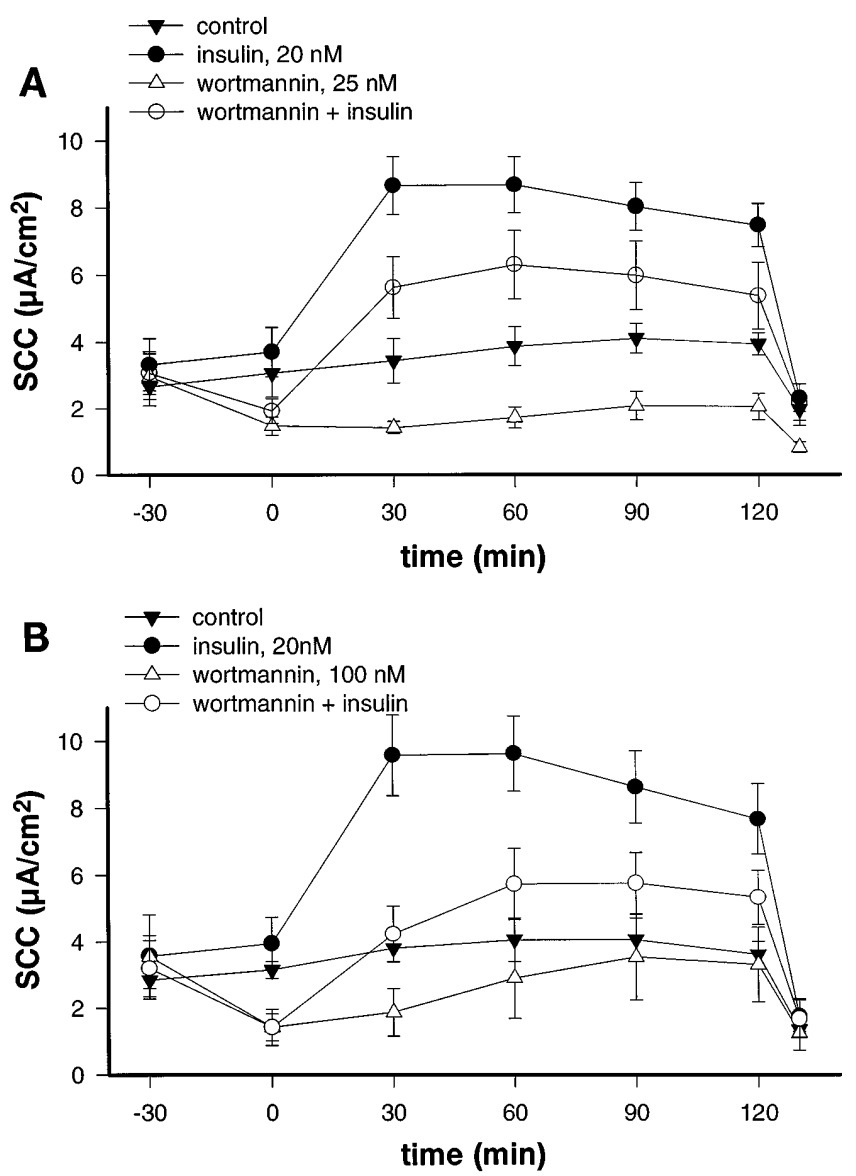

Fig. 2. Wortmannin effects on insulin-stimulated sodium transport. A6 cells were preincubated with wortmannin ( $25 \mathrm{nM}, \mathrm{A} ; 100 \mathrm{nM}, \mathrm{B})$ bilaterally for $30 \mathrm{~min}$. Insulin ( $20 \mathrm{nM}$ ) was added serosally at time 0 . After 120 min of insulin, $10 \mu \mathrm{M}$ amiloride was added apically. Results are means $\pm S E ; n=4$ in $A ; n=2$, $B$. 

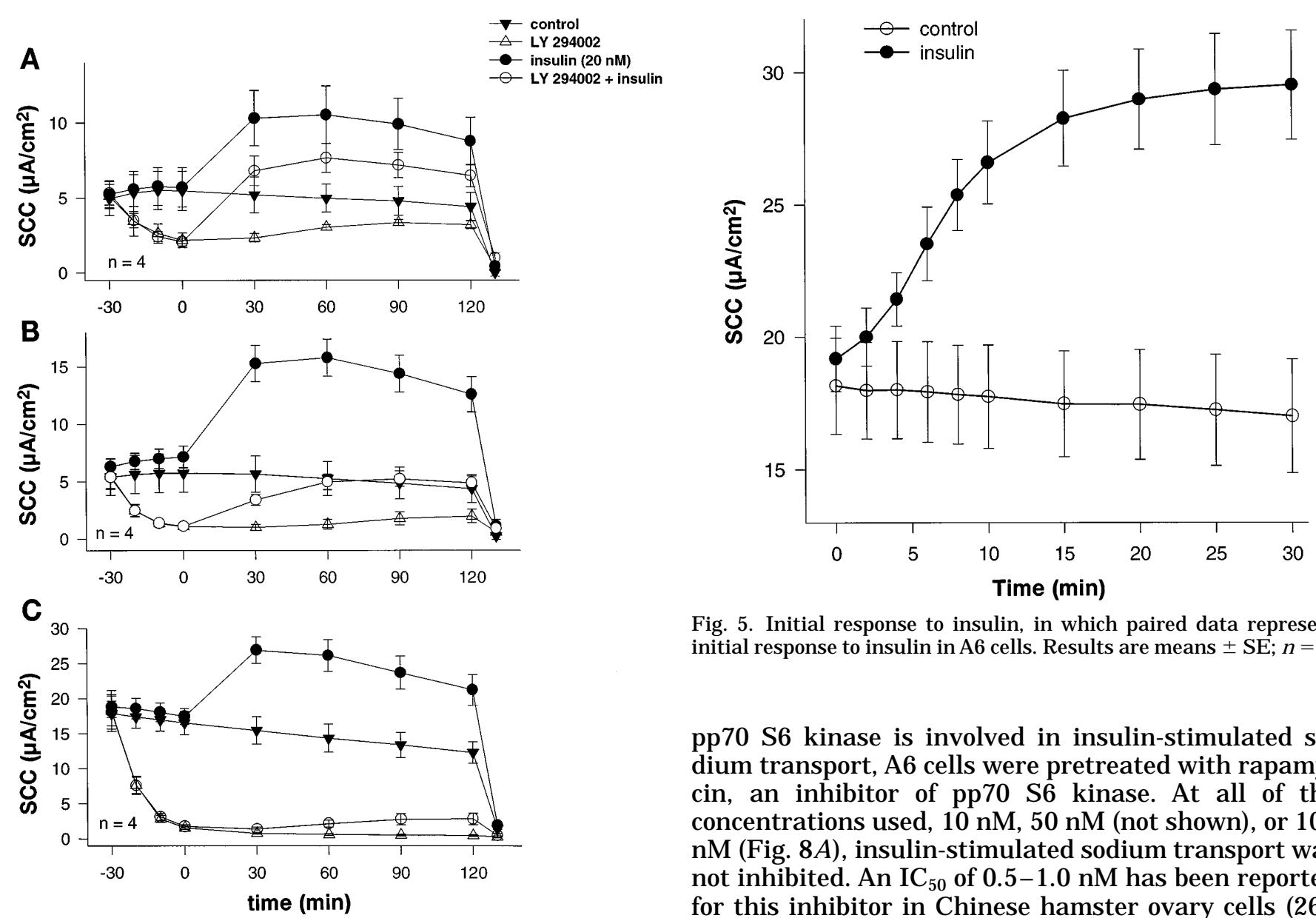

Fig. 5. I nitial response to insulin, in which paired data represent initial response to insulin in A6 cells. Results are means $\pm S E ; n=4$.

pp70 S6 kinase is involved in insulin-stimulated sodium transport, A6 cells were pretreated with rapamycin, an inhibitor of pp70 S6 kinase. At all of the concentrations used, $10 \mathrm{nM}, 50 \mathrm{nM}$ (not shown), or 100 nM (Fig. 8A), insulin-stimulated sodium transport was not inhibited. An IC $\mathrm{C}_{50}$ of 0.5-1.0 nM has been reported for this inhibitor in Chinese hamster ovary cells (26).

Fig. 3. 2-(4-Morpholinyl)-8-phenyl-4H-1-benzopyren-4-one (LY-294002) inhibits insulin-stimulated sodium transport in a concentration-dependent manner. A6 cells were preincubated in LY-294002 bilaterally for 30 min. LY-294002 was added at final concentrations of 2 (A), 10 (B ), and 50 (C) $\mu \mathrm{M}$, as indicated. Insulin ( $20 \mathrm{nM})$ was added serosally at time 0 . Results are means $\pm \mathrm{SE} ; \mathrm{n}=4$.

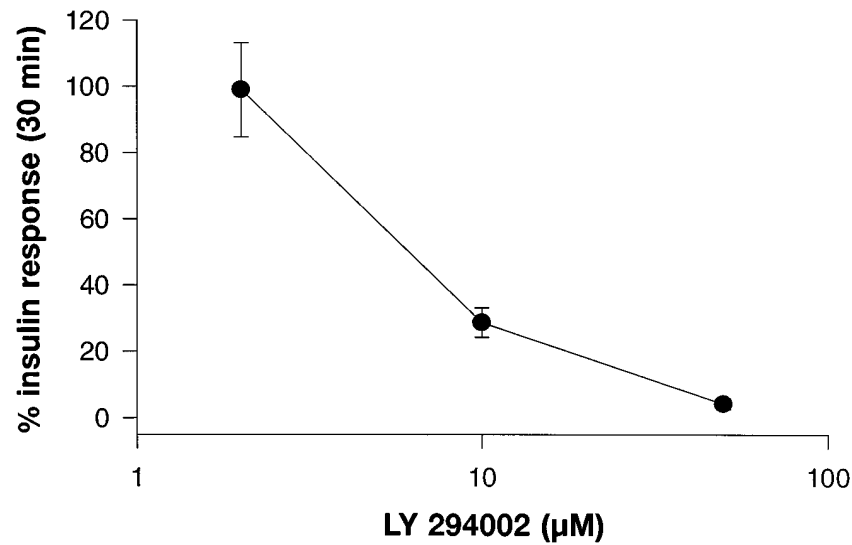

Fig. 4. Dose-response curve for the effect of LY-294002 on insulinstimulated sodium transport. Data depicted in Fig. 3 were used to construct a limited dose-response relationship. The $\% \Delta S C C$ of insulin al one at $30 \mathrm{~min}$ after insulin addition are plotted vs. concentration of LY-294002 (log scale). Results are means $\pm S E ; n=4$.
However, rapamycin did inhibit insulin-stimulated S6 kinase activity in pp70 S6 kinase immunoprecipitations from the $\mathrm{A} 6$ cell (Fig. 8B), indicating that pp70 S6 kinase, although present in A6 cells and inhibited by

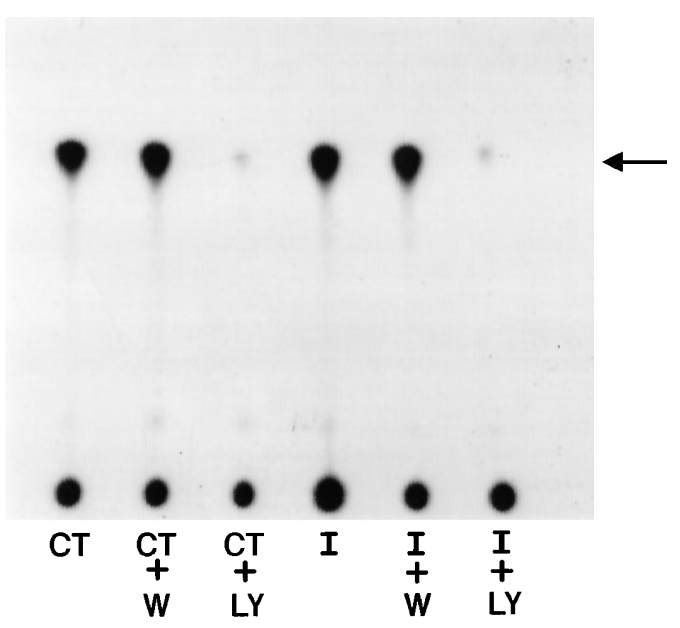

Fig. 6. In vitro PI 3-kinase activity. Serum-starved (16-h) A6 cells were treated with (I) or without (CT) $100 \mathrm{nM}$ insulin for 5 min and solubilized. Solubilized proteins were immunoprecipitated with anti-PI 3-kinase 85-kDa subunit. I mmunoprecipitates were assayed for activity with or without $25 \mathrm{nM}$ wortmannin (W) or $50 \mu \mathrm{M}$ LY-294002 (LY); lipids were extracted and separated by thin-layer chromatography (TLC). Arrow indicates phosphatidylinositol (Ptdl ns) monophosphate. Data are representative of 5 experiments. 

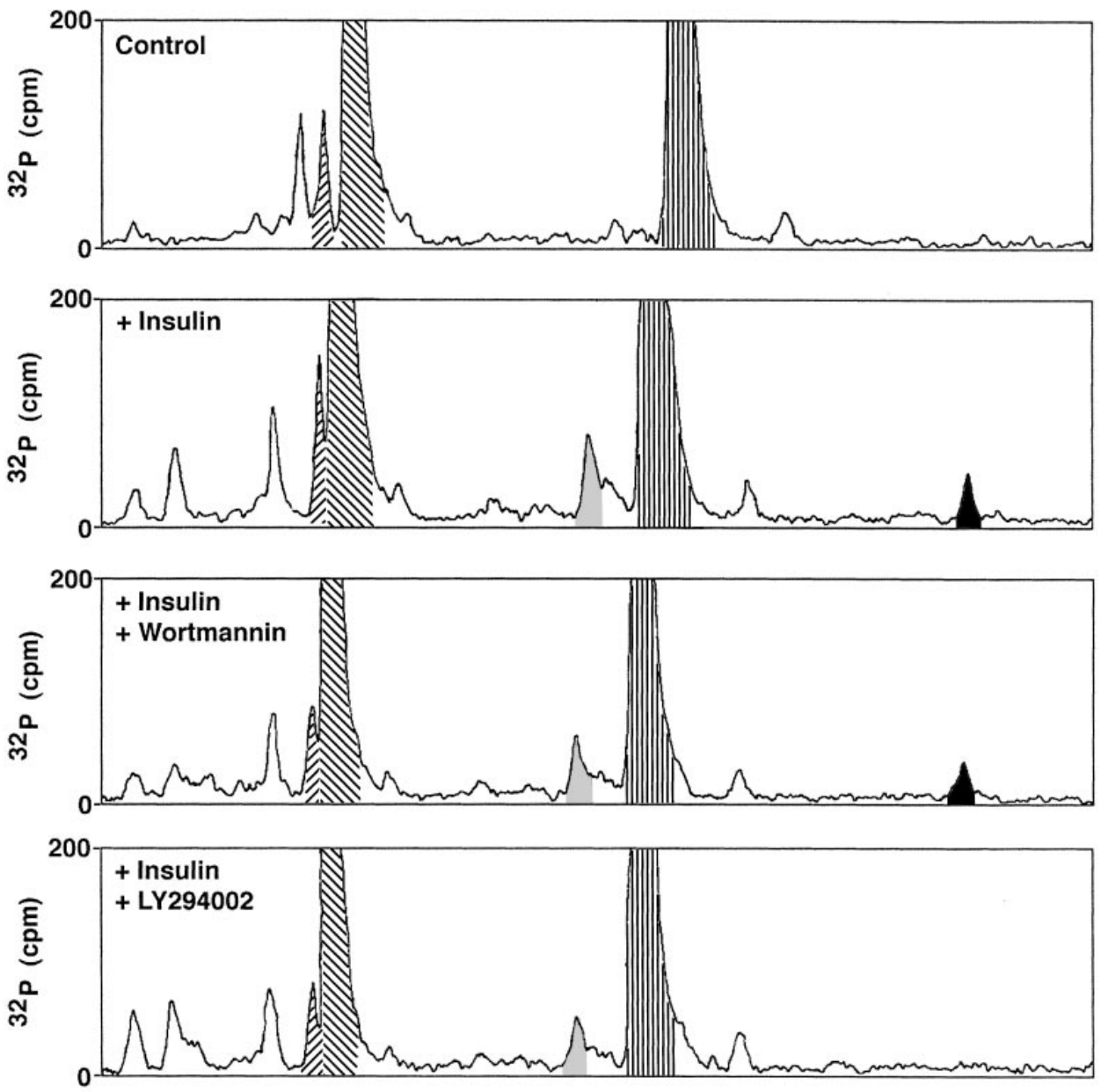

Fig. 7. In vivo PI 3-kinase activity. Serum-starved (16-h) A6 cells were metabolically labeled with ${ }^{32} \mathrm{P}_{\mathrm{i}}$ for $2 \mathrm{~h}$, followed by $20 \mathrm{~min}$ with or without 25 $\mathrm{nM}$ wortmannin or $50 \mu \mathrm{M}$ LY-294002. Preliminary experiments determined that stimulation for $1 \mathrm{~min}$ with $100 \mathrm{nM}$ insulin (data not shown) was sufficient for production of detectable phosphatidylinositol 3,4,5-trisphosphate [Ptdl ns(3,4,5)P]. After stimulation with insulin, cells were harvested, and lipids were extracted and separated by TLC. Phosphorylated Ptdl ns were extracted from TLC plates, deacylated, and analyzed by anionexchange HPLC. [ $\left.{ }^{3} \mathrm{H}\right] \mathrm{Ptdl} n \mathrm{~ns}(4) \mathrm{P}$ and $\left[{ }^{3} \mathrm{H}\right] \mathrm{Ptdl} \mathrm{ns}(4,5) \mathrm{P}$ were used as internal standards (Std). Data are representative of 3 experiments.

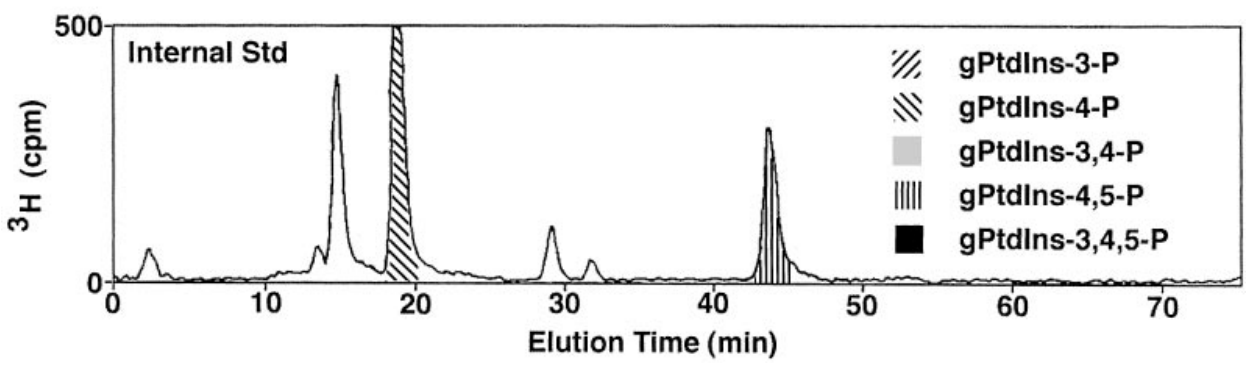

rapamycin, is not involved in insulin-stimulated sodium transport.

\section{DISCUSSION}

Previous work has demonstrated that insulin stimulates the amiloride-sensitive epithelial sodium channel in models of the distal nephron. The mechanism of how basolaterally presented insulin can affect the channel in the apical membrane has not been elucidated. We have previously demonstrated that insulin specifically binds the basolateral membrane of amphibian cells and that the insulin receptor is immunol ogically local ized to the same membrane (5). In this report, we demonstrate that an inhibitor of the IRTK, HNMPA-(AM) $)_{3}$, can inhibit insulin-stimulated sodium transport (Fig. 1). However, it should be noted that HNMPA-(AM $)_{3}$ also has an effect on basal transport, so we cannot exclude effects of the inhibitor on tyrosine kinases other than the insulin receptor.

Insulin has pleiotropic effects mediated by several postreceptor signaling pathways. A key enzyme activated by insulin is PI 3-kinase. Activation of this enzyme is required for the insertion of the insulinsensitive glucose transporter (GLUT-4) into the plasma membrane and for activation of pp70 S6 kinase, which is involved in protein synthesis. We used a specific inhibitor of PI 3-kinase, LY-294002, to demonstrate that insulin-stimulated sodium transport al so requires activation of this enzyme (Fig. 3). Because intracellular pathways are stimulated before the manifestation of a final effect on transcellular transport, we measured PI 3-kinase activity in the very early phase of the insulin response. $\mathrm{PI} 3$-kinase is present in A6 cells and can be inhibited both in vitro (Fig. 6) and in vivo (Fig. 7) by 

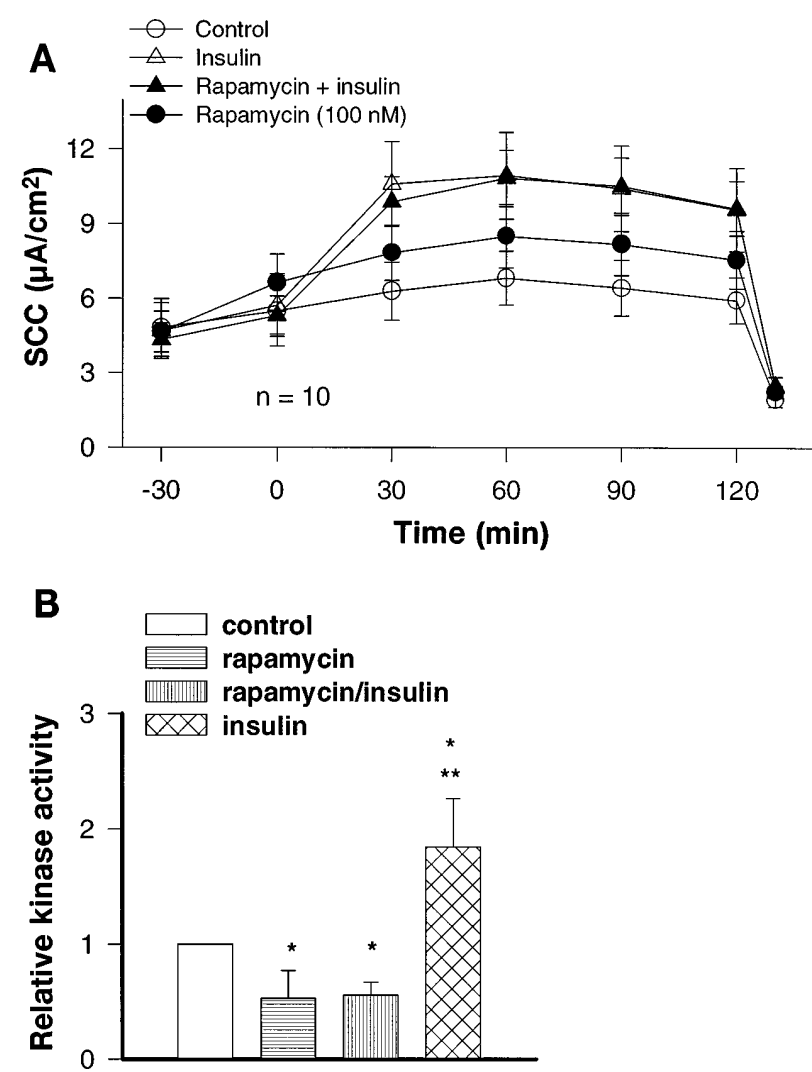

Fig. 8. Effects of $100 \mathrm{nM}$ rapamycin on insulin-stimulated sodium transport and pp70 S6 kinase. A: A6 cells were pretreated with 100 $\mathrm{nM}$ rapamycin bilaterally for $30 \mathrm{~min}$. Insulin ( $20 \mathrm{nM}$ ) was added serosally at time 0 . After $120 \mathrm{~min}$ of insulin, $10 \mu \mathrm{M}$ amiloride was added apically. Results are means $\pm \mathrm{SE} ; \mathrm{n}=9$. $\mathrm{B}$ : serum-starved $\mathrm{A} 6$ cells were treated with or without $100 \mathrm{nM}$ rapamycin for $30 \mathrm{~min}$, followed by $5 \mathrm{~min}$ with or without $100 \mathrm{nM}$ insulin. Solubilized proteins were immunoprecipitated with anti-pp70 S6 kinase. I mmunoprecipitates were assayed for activity. Results are expressed as multiples of control level, means $\pm \mathrm{SE} ; \mathrm{n}=5$. $* \mathrm{P}<0.05$ vs. control; ** $\mathrm{P}<0.01$ vs. rapamycin and insulin.

LY-294002. The inability of wortmannin to completely inhibit PI 3-kinase in these cells (Fig. 2) may be characteristic of Xenopus laevis; others have reported a PI 3-kinase with similar sensitivities to LY-294002 and wortmannin in Xenopus laevis oocytes (29). Although the initial effects of LY-294002 and wortmannin were similar, the wortmannin effect was not sustained over time and was less complete than that of LY-294002. Our functional assay provides a unique opportunity to monitor the inhibitor effect continuously over long time courses and may, therefore, detect interactions or effects that are not easily assessed in other systems.

In Chinese hamster ovary cells, activation of PI 3-kinase is necessary for pp70 S6 kinase activation and subsequent protein synthesis (26). Rapamycin, an immunosuppressant and inhibitor of pp70 56 kinase, was used to reveal that pp70 S6 kinase is not involved in insulin-stimulated sodium transport (Fig. 8A). Although the pp70 S6 kinase is present in A6 cells, is activated by insulin, and can be inhibited by rapamycin (Fig. 8B), it does not appear to be involved in the natriferic effect of insulin.
Insulin-activated PI 3-kinase is necessary for the transl ocation of GLUT-4 from a cytosol ic pool of vesicles to the plasma membrane of adipocytes and skeletal muscle. Although the steps downstream of PI 3-kinase are not known, it is thought that the activation of PI 3-kinase brings the enzyme to its substrates (Ptdl ns) in the membrane and that the lipids are the mediators of insulin signaling (17). We would suggest that this pathway may also be utilized for insulin-stimulated sodium transport.

Several groups have demonstrated that insulin induces an increase in the number of active sodium channels in the apical membrane. Preliminary reports indicate that insulin increases channel density in the apical membranes of A6 cells $(2,4)$. Published experiments demonstrate that insulin increases the apical membrane area and the number of open sodium channels in the apical membrane (11). These results suggest that insulin induces the exocytotic insertion of sodium channels into the apical membrane. This hypothesis is supported by experiments with brefeldin A, an inhibitor of exocytosis, which also inhibits insulin-stimulated sodium transport (9). Conversely, patch-clamp experiments demonstrated an insulin-stimulated increase in $\mathrm{P}_{0}$, the sodium channel. These results could not be confirmed by using noise analysis (4). The reasons for this discrepancy are not obvious, and we can only suggest that blocker-induced noise analysis is a less invasive procedure that will not perturb potential signaling pathways, such as those involving the cellular cytoskel eton.

There is precedence for transporters to be translocated in response to stimuli. In addition to GLUT-4, water channels (aquaporin) are inserted into the apical membrane of amphibian skin and urinary bladder and mammalian kidney epithelia in response to antidiuretic hormone (16); in stimulated gastric parietal cells, $\mathrm{H}^{+}-\mathrm{K}^{+}$-ATPase is redistributed to the apical surface (15); and the number of $\mathrm{H}^{+}$ATPases found in turtle bladder apical membrane increases in response to carbon dioxide (6). Thus the hypothesis that sodium channels are exocytotically inserted into the apical membrane in response to insulin is reasonable.

PI 3-kinase has recently been shown to mediate epidermal growth factor (EGF) stimulation of intestinal $\mathrm{NaCl}$ absorption and $\mathrm{Na}^{+} / \mathrm{H}^{+}$exchange (18). The ion transport occurs at the ileal brush-border membrane; the EGF receptor is located at the basolateral membrane. The authors suggest that PI 3-kinase may be directly associating with $\mathrm{Na}^{+} / \mathrm{H}^{+}$exchangers, because the $\mathrm{SH} 3$ domain of the PI 3-kinase $85-\mathrm{kDa}$ subunit could interact with proline-rich sequences in the exchanger. Similarly, the $\alpha$-subunit of the sodium channel also contains proline-rich regions (28) that may directly interact with PI 3-kinase in A6 cells. These are suggestive of interactions within the prolinerich region of effector proteins. However, it is also possible that the lipid products of PI 3-kinase can directly interact with effectors and regulate activity. In this regard, it is unclear whether $\mathrm{PI}(3,4) \mathrm{P}_{2}$ or $\mathrm{PI}(3,4,5) \mathrm{P}_{3}$ $\left(\mathrm{PIP}_{3}\right)$ would be the crucial product for signal transduc- 
tion in this system. Both molecules have been shown to regulate various signaling systems (30). However, it is interesting to note that $L Y-294002$ inhibits $\mathrm{PIP}_{3}$ production and (subsequently) sodium transport, whereas wortmannin has no effect on $\mathrm{PIP}_{3}$ production and little sustained effect on sodium transport in these cells. However, more experiments need to be performed before it is possible to state that $\mathrm{PIP}_{3}$ is the crucial product for signaling in this epithelium or whether the PI 3-kinase may have a more direct action on the channel components.

In conclusion, we demonstrate for the first time that PI 3-kinase is necessary for insulin-stimulated sodium transport. We suggest that insulin may induce the insertion of sodium channels into the apical membrane of A6 cells in a manner analogous to insulin-stimulated translocation of GLUT-4.

We thank Drs. Simon Rhodes and J udy Boyd-White for critically reviewing this manuscript and Dr. Ray Russo for help with the computer graphics.

This work was supported by a Veterans Affairs Merit Review grant and a Grant-in-Aid from the American Heart Association, Indiana Affiliate (to B. L. Blazer-Yost).

Address for reprint requests: B. L. Blazer-Yost, Biology Dept., I.U.P.U.I., 723 W. Michigan St., Indianapolis, IN 46202.

Received 15 J uly 1997; accepted in final form 8 J anuary 1998.

\section{REFERENCES}

1. Baltensperger, K., R. E. Lewis, C.-W. Woon, P. Vissavajjhala, A. H. Ross, and M. P. Czech. Catalysis of serine and tyrosine autophosphorylation by the human insulin receptor. Proc. Natl. Acad. Sci. USA 89: 7885-7889, 1992.

2. Baxendale, L. M. Insulin increases apical sodium channel density in A6 epithelia (Abstract). FASE B J . 2: A748, 1988.

3. Blazer-Yost, B. L., Y. Fesseha, and M. Cox. Aldosterone mediated $\mathrm{Na}^{+}$transport in renal epithelia: time-course of induction of a potential regulatory component of the conductive $\mathrm{Na}^{+}$ channel. Biochem. Int. 26: 887-897, 1992.

4. Blazer-Yost, B. L., X. Liu, and S. I. Helman. Insulin stimulated $\mathrm{Na}^{+}$transport is mediated by increase of apical $\mathrm{Na}^{+}$ channels and not open probability in control and aldosterone prestimulated A6 epithelia (Abstract). FASE B J . 10: A78, 1996.

5. Blazer-Yost, B. L., N. Shah, L. J arett, M. Cox, and R. M. Smith. Insulin and IGF 1 receptors in a model renal epithelium: receptor localization and characterization. Biochem. Int. 28: 143-153, 1992

6. Cannon, C., J . van Adelsberg, S. Kelly, and Q. Al-Awqati. Carbon-dioxide-induced exocytotic insertion of $\mathrm{H}^{+}$pumps in turtle-bladder luminal membrane: role of cell $\mathrm{pH}$ and calcium. Nature 314: 443-446, 1985.

7. Cheatham, B., C. J . Vlahos, L. Cheatham, L. Wang, J . Blenis, and C. R. Kahn. Phosphatidylinositol 3-kinase activation is required for insulin stimulation of pp70 S6 kinase, DNA synthesis, and glucose transporter translocation. Mol. Cell. Biol. 14: 4902-4611, 1994.

8. Clarke, N. G., and R. M. C. Dawson. Alkaline $\mathrm{O} \rightarrow \mathrm{N}$ transacylation. Biochem. J . 195: 301-306, 1981.

9. Coupaye-Gerard, B., H. J . Kim, A. Singh, and B. L. BlazerYost. Differential effects of brefeldin A on hormonally regulated $\mathrm{Na}^{+}$transport in a model renal epithelial cell line. Biochim. Biophys. Acta 1190: 449-456, 1994.

10. Defronzo, R. A. The effect of insulin on renal sodium metabolism. Diabetol ogia 21: 165-171, 1981.

11. Erlij, D., P. De Smet, and W. Van Driessche. Effect of insulin on area and $\mathrm{Na}^{+}$channel density of apical membrane of cultured toad kidney cells. J. Physiol. (Lond.) 481: 533-542, 1994.

12. Fidelman, M. L., J. M. May, T. U. L. Biber, and C. $\mathbf{O}$. Watlington. Insulin stimulation of $\mathrm{Na}^{+}$transport and glucose metabolism in cultured kidney cells. Am. J . Physiol. 242 (Cell Physiol. 11): C121-C123, 1982.
13. Folch, J ., M. Lees, and G. H. Sloane Stanley. A simple method for the isolation and purification of total lipids from animal tissues. J . Biol. Chem. 226: 497-509, 1957.

14. Herrera, F. C. Effect of insulin on short-circuit current and sodium transport across toad urinary bladder. Am. J . Physiol. 209: 819-824, 1965.

15. Hirst, B. H., and J . G. Forte. Redistribution and characterization of $\left(\mathrm{H}^{+}+\mathrm{K}^{+}\right)$-ATPase membranes from resting and stimulated gastric parietal cells. Biochem. J . 231: 641-649, 1985.

16. J o, I., and H. W. Harris, J r. Molecular mechanisms for the regulation of water transport in amphibian epithelia by antidiuretic hormone. Kidney Int. 48: 1088-1096, 1995.

17. Kapeller, R., and L. C. Cantley. Phosphatidylinositol 3-kinase. BioEssays 16: 565- 576, 1994.

18. Khurana, S., S. K. Nath, S. A. Levine, J . M. Bowser, C.-M. Tse, M. E. Cohen, and M. Donowitz. Brush border phosphatidylinositol 3-kinase mediates epidermal growth factor stimulation of intestinal $\mathrm{NaCl}$ absorption and $\mathrm{Na}^{+} / \mathrm{H}^{+}$exchange. J . Biol. Chem. 271: 9919-9927, 1996.

19. Koefoed-J ohnsen, V., and H. H. Ussing. The nature of the frog skin potential. Acta Physiol. Scand. 42: 298-308, 1958.

20. Marunaka, Y., N. Hagiwara, and H. Tohda. Insulin activates single amiloride-blockable $\mathrm{Na}$ channels in a distal nephron cell line (A6). Am. J. Physiol. 263 (Renal Fluid Electrolyte Physiol. 32): F 392-F 400, 1992.

21. Nizet, A., P. Lefebvre, and J . Crabbe. Control by insulin of sodium, potassium and water excretion by the isolated dog kidney. Pflugers Arch. 323: 11-20, 1971.

22. Perkins, F. M., and J . S. Handler. Transport properties of toad kidney epithelia in culture. Am. J . Physiol. 241 (Cell Physiol. 10): C154-C159, 1981.

23. Powis, G., R. Bonjouklian, M. M. Berggren, A. Gallegos, R. Abraham, C. Ashendel, L. Zalkow, W. F. Matter, J . Dodge, G. Grindey, and C.J . Vlahos. Wortmannin, a potent and selective inhibitor of phosphatidylinositol-3-kinase. Cancer Res. 54: 24192423, 1994

24. Proud, C. G. p70 56 kinase: an enigma with variations. Trends Biochem. Sci. 21: 181-185, 1996.

25. Record, R. D., M. J ohnson, S. Lee, and B. L. Blazer-Yost. Aldosterone and insulin stimulate amiloride-sensitive sodium transport in A6 cells by additive mechanisms. Am. J . Physiol . 271 (Cell Physiol. 40): C1079-C1084, 1996.

26. Redpath, N. T., E. J . Foulstone, and C. G. Proud. Regulation of translation elongation factor-2 by insulin via a rapamycinsensitive signalling pathway. EMBO J . 15: 2291-2297, 1996.

27. Rodriguez-Commes, J ., C. I sales, L. Kalghati, J . GasallaHerraiz, and J . P. Hayslett. Mechanism of insulin-stimulated electrogenic sodium transport. Kidney I nt. 46: 666-674, 1994

28. Rotin, D., D. Bar-Sagi, H. O'Brodovich, J . Merilainen, V. P. Lehto, C. M. Canessa, B. C. Rossier, and G. P. Downey. An $\mathrm{SH} 3$ binding region in the epithelial $\mathrm{Na}^{+}$channel $(\alpha \mathrm{rENaC})$ mediates its localization at the apical membrane. EMBO J . 13: 4440-4450, 1994.

29. Thomson, F. J ., C. Moyes, P. H. Scott, R. Plevin, and G. W. Gould. Lysophosphatidic acid stimulates glucose transport in Xenopus oocytes via a phosphatidylinositol 3'-kinase with distinct properties. Biochem. J . 316: 161-166, 1996.

30. Toker, A., and L. C. Cantley. Signalling through the lipid products of phosphoinositide-3-OH kinase. Nature 387: 673-676, 1997

31. Vlahos, C. J., and W. F. Matter. Signal transduction in neutrophil activation. Phosphatidylinositol 3-kinase is stimulated without tyrosine phosphorylation. FEBS Lett. 309: 242248, 1992.

32. Vlahos, C. J ., W. F. Matter, K. Y. Hui, and R. F. Brown. A specific inhibitor of phosphatidylinositol 3-kinase, 2-(4-morpholinyl)-8-phenyl-4H-1-benzopyran-4-one (LY294002). J . Biol . Chem. 269: 5241-5248, 1994.

33. White, M. F. The IRS-signalling system in insulin and cytokine action. Phil. Trans. R. Soc. Lond. B 351: 181-189, 1996.

34. Yeh, J .-I., E. A. Gulve, L. Rameh, and M. J . Birnbaum. The effects of wortmannin on rat skeletal muscle. J . Biol. Chem. 270: 2107-2111, 1995. 